\title{
Article
}

\section{When managers create knowledge, they also kill creativity}

\author{
Kakoudakis, Konstantinos
}

Available at http://clok.uclan.ac.uk/34850/

Kakoudakis, Konstantinos (2020) When managers create knowledge, they also kill creativity. Annals of Tourism Research, 80 (102824). ISSN 0160-7383

It is advisable to refer to the publisher's version if you intend to cite from the work. http://dx.doi.org/10.1016/j.annals.2019.102824

For more information about UCLan's research in this area go to http://www.uclan.ac.uk/researchgroups/ and search for < name of research Group>.

For information about Research generally at UCLan please go to http://www.uclan.ac.uk/research/

All outputs in CLoK are protected by Intellectual Property Rights law, including Copyright law. Copyright, IPR and Moral Rights for the works on this site are retained by the individual authors and/or other copyright owners. Terms and conditions for use of this material are defined in the policies page.

\section{CLoK}

Central Lancashire online Knowledge www.clok.uclan.ac.uk

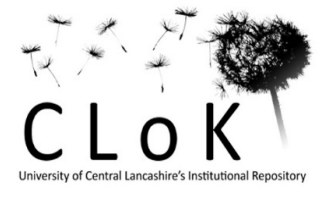


Tourism Research

Elsevier Editorial System(tm) for Annals of Manuscript Draft

Manuscript Number: ATR-D-19-00602R1

Title: When managers create knowledge, they also kill creativity

Article Type: View Point

Corresponding Author: Dr. Konstantinos I. Kakoudakis, Ph.D.

Corresponding Author's Institution: University of Central Lancashire, Cyprus Campus

First Author: Konstantinos I. Kakoudakis, Ph.D.

Order of Authors: Konstantinos I. Kakoudakis, Ph.D.

Manuscript Region of Origin: CYPRUS 


\section{Cover Letter}

Dear Editors,

I would like to thank you for taking the time to review my manuscript, and for your insightful and constructive feedback. I very much appreciate that you found my viewpoint interesting. I also appreciate your comments and suggestions, which helped me to refocus my argument and revise the manuscript.

The title of the revised manuscript is 'When Managers Create Knowledge, They Also Kill Creativity,' and it is based on one of your suggestions. It focuses on the increasing bureaucracy in modern universities, and the implications of this phenomenon for the creativity of faculty members. Therefore, I believe it is a very current issue that all academics face, to a larger or lesser extent.

I believe that I have addressed your concerns, and I have been able to respond to the points that you have raised, and I hope that you will find the revised Viewpoint interesting.

Thank you very much for your time and consideration.

Yours sincerely,

Konstantinos I. Kakoudakis 


\section{Author name and affiliation:}

\section{Konstantinos I. Kakoudakis}

University of Central Lancashire, Cyprus Campus, School of Business and Management, 1214 University Avenue, Pyla, 7080 Larnaka Cyprus

Corresponding author: Konstantinos I. Kakoudakis

University of Central Lancashire, Cyprus Campus

School of Business and Management

12-14 University Avenue

Pyla 7080, Larnaka

Cyprus

Email address: kkakoudakis@uclan.ac.uk

Telephone: +357 24694071

\section{Author bio:}

Konstantinos I. Kakoudakis is a Lecturer in Hospitality \& Tourism Management at University of Central Lancashire, Cyprus Campus < kkakoudakis@uclan.ac.uk>. His research interests are in social tourism, sustainable development, and working conditions in the Hospitality industry. He was previously Researcher/Consultant in tourism development projects co-funded by the EU, while he has also several years of work experience in the tourism industry. He holds a Ph.D. from the University of Nottingham, UK. 


\section{Manuscript ID: ATR-D-19-00602R1}

Dear Reviewers. I would like to thank you for taking the time to review my manuscript, and for your insightful and constructive feedback. I very much appreciate that you found my viewpoint interesting. I also appreciate your comments and suggestions, which gave me the chance to rethink important issues in relation to succinct academic writing, and to refocus the paper's argument. I revised the manuscript according to your suggestions, and I believe that I have addressed your concerns, and I have been able to respond to the points that you have raised. Thank you very much for your time and consideration.

\begin{tabular}{|c|c|}
\hline Reviewers' comments & Our response \\
\hline \multicolumn{2}{|l|}{ Paper overview } \\
\hline $\begin{array}{l}\text { You have a number of good points in there, each } \\
\text { of which is good enough for a viewpoint. But } \\
\text { currently they are all mashed up and so all of } \\
\text { them get lost. Basically, I would recommend you } \\
\text { think about which ONE point you want to } \\
\text { convey. } \\
\text { Here are the points I like: POSSIBLE TITLE: } \\
\text { The sick scholar I think this discussion is a really } \\
\text { important one. We are having it now with elite } \\
\text { athletes who fall into a slump when they stop } \\
\text { competing, but we really do not talk about the } \\
\text { health of academics. So this also could be a } \\
\text { viewpoint. But I would recommend backing your } \\
\text { views with a bit more evidence, some interesting } \\
\text { facts maybe. It would be interesting to just think } \\
\text { about what being an academic meant } 20 \text { years } \\
\text { ago and what it means now on a daily basis. In } \\
\text { my view it is unrecognizable! }\end{array}$ & $\begin{array}{l}\text { Thank you very much for your recommendations. } \\
\text { The revised manuscript has been largely } \\
\text { rewritten, and now focuses on one point only, and } \\
\text { more specifically, on the third topic that you have } \\
\text { suggested, which revolves around the increasing } \\
\text { bureaucracy in modern universities, and the } \\
\text { implications of this phenomenon for the creativity } \\
\text { of faculty members. }\end{array}$ \\
\hline $\begin{array}{l}\text { POSSIBLE TITLE: Better work for google That } \\
\text { is a follow on form the previous points. You } \\
\text { know, I cannot recommend to smart young } \\
\text { people to go into academic anymore. It is no } \\
\text { longer the place for brilliant minds to be. Rather, } \\
\text { it has become the perfect breeding ground for } \\
\text { compliant, mediocre people. So if I were } 20 \\
\text { again, I would go to google to change the world. } \\
\text { You cannot change the world in a university } \\
\text { anymore. Maybe the title should be Academic } \\
\text { Brain Drain. }\end{array}$ & \\
\hline POSSIBLE TITLE: When managers create & \\
\hline
\end{tabular}




\begin{tabular}{l|l|}
\hline knowledge I really love this point and I think, \\
again, it is actually not one that has been openly \\
and professionally discussed, we just chat about it \\
in tearooms. I think it would be fascinating to \\
illustrate in a viewpoint the madness that any \\
creativity that is needed to have brilliant ideas is \\
killed by a wide array of bureaucratic processes. \\
Well, and then thre is the topic with which you \\
start: \\
POSSIBLE TITLE: Universities 2020 - no place \\
for oddballs Would it not be interesting to wirte a \\
piece where you can provide evidence that most \\
people who had brilliant ideas were not your \\
average citizens. They were mad, they were \\
obsessive compulsive, they had social anxieties, \\
they were square pegs in round holes. And today \\
universities would simply not hire them anymore. \\
That is the real drama, is it not
\end{tabular}

Once again, I would like to thank you for your insightful and constructive feedback on my manuscript, and I hope that the response above has addressed the concerns you raised. 
When managers create knowledge, they also kill creativity

Over the past two decades, universities have changed direction, adopting structures, strategies, and aims that resemble those of corporations. The marketisation of the sector has led to managerialism, focusing primarily on profit, control and efficiency, values that are inherent in the neoliberal corporate culture (Giroux, 2002). Managerialism is driven by stringent external accountability requirements, largely imposed by governments, which have increased their influence over educational policy in several countries (Kenny, 2009). As a result, universities have diverted their attention from the core tasks of teaching, research, and contribution to society, to developing policies, ticking boxes and trying to climb up rankings (Spicer, 2017).

Martin (2016, pp. 7-14) calls these processes "bureaucratic nonsense" and stresses that "it is difficult to think of any academic activity that has become less bureaucratic." Indeed, bureaucracy does not only comprise a significant addition to our workload, interfering daily with our core duties, but it is, often, prioritised by management over these duties. It could be argued that our job descriptions tend to resemble those of administrators; and it often feels like the only difference being that on the top of paperwork, we have also some teaching and research to do. While acknowledging that there is a certain degree of exaggeration in this argument, our increasing involvement with a wide array of bureaucratic processes, ranging from endless emailing and meetings (about anything), to filling out endless forms and reports (any kind of them), consumes a substantial amount of our time and energy, holding severe implications for scholarship. Inevitably, we have less time and energy for class preparation and research, while in parallel, we feel guilty that we do not work hard enough, and a constant pressure to speed up (Berg and Seeber, 2016).

Our usual response to these adversities includes multitasking and devoting late evenings and weekends to work, often, at the expense of family and friends. This may be partly due to our high 'self-imposed' expectations as academics, but there is no doubt that it escalates because of management pressures as a result of the increasing competition in the sector. But in any case, and no matter what we do, as the demands from our employers are often unrealistic, there is a constant mismatch between our 'to 
do' list and the time we have at our disposal. So can we really do any creative work under these circumstances?

Both anecdotal and research evidence confirm that we cannot; and we chat about it quietly in the corridors and tearooms. Time, for example, is one of the main resources that affect creativity, and work environments that do not allow time for exploration, kill creativity (Amabile, 1998). Indeed, we cannot produce creative ideas when we do not have available time for deep contemplative and uninterrupted thinking (e.g. Han, 2015) or when we do not experience a sense of timelessness as Mainemelis (2001) points out. Moreover, the lack of time adds significantly to our stress levels, which, in turn, has a negative impact on creative work, resulting in research that lacks creativity and innovation (e.g. Miller, 2011). The same applies to the consequences of increased control over creative activities. Researchers, for instance, do not have much freedom any more to create knowledge as they wish. Instead, they are expected to comply with decisions and guidelines of managers who do not understand the process of knowledge creation (Berg and Seeber, 2016). The oxymoron is that although universities emphasise bureaucracy, which, by definition, entails following a beaten track, they also desire creativity, which requires freedom and 'madness', and, hence, stepping off the beaten track (Hirst et al., 2011, p. 625).

Arguably, the life-time works of creative people, such as pioneers in science, the arts, and architecture, were not only the results of individual traits, but also of specific conditions that encouraged their creativity, and allowed it to flourish. In contrast, the highly bureaucratic organisational conditions in universities are particularly hostile to creativity. This detachment of the modern university from the fundamentals of the academic vocation is demoralising for faculty members who have the potential to produce creative work, and impedes innovation, and the advancement of knowledge. What happens instead is that the knowledge we were supposed to produce as academics is now produced by managers, and it is neither novel nor useful, neither for academia, nor for the wider community. Sadly, this reality conflicts both with the principal aims of Higher Education, and the ideals that largely influenced our career choices, such as passion for exploration and creative thinking that may lead to the generation of new ideas and benefit society. Actually, by killing creativity, bureaucracy also kills the very ideals of our vocation. 


\section{References}

Amabile, T. M. (1998). How to kill creativity. Harvard Business Review, Sept/Oct, 77-87.

Berg, M., and Seeber, B. K. (2016). The slow Professor. Challenging the culture of speed in the Academy. Toronto, Buffalo, London: University of Toronto Press.

Giroux, H. (2002). Neoliberalism, Corporate culture and the promise of Higher Education: the university as a democratic public sphere. Harvard Educational Review, 72(4), pp. 425-464.

Han, BC. (2015). The burnout society. Stanford, California: Stanford University Press.

Hirst, G., Van Knippenberg, D., Chen, C. H., and Sacramento, C. A. (2011). How does bureaucracy impact individual creativity? A cross-level investigation of team contextual influences on goal orientation-creativity relationships. Academy of Management Journal, 54(3), 624-641.

Kenny, J. D. (2009) Managing a modern university: is it time for a rethink? Higher Education Research \& Development, 28(6), 629-642.

Mainemelis, C. (2001). When the muse takes it all: A model for the experience of timelessness in organizations. Academy of Management Review, 26(4), 548-565.

Martin, B. R. (2016). What's happening to our universities?, Prometheus, 34(1), 7-24. Miller, A.N., Taylor, S.G., and Bedeian, A.G. (2011). Publish or perish: academic life as management faculty live it. Career Development International, 16(5), 422-445.

Spicer, A. (2017). Universities are broke. So let's cut the pointless admin, and get back to teaching. The Guardian, 21 August. Retrieved from https://www.theguardian.com/commentisfree/2017/aug/21/universities-broke-cutpointless-admin-teaching, last accessed 9.9.2019. 